\title{
Training Initiation Date Affects Height of Nursery Olive Trees
}

\author{
Carmen del Río and \\ Abdeslam Proubi
}

ADDITIONAL INDEX WORDS. propagation, pruning, single-shoot, forced growth.

Summary. An experiment was carried out to determine when to initiate training potted rooted cuttings of olive (Olea europaea L.), so that tall and well developed nursery trees could be produced in an 8-month growing season. Initiating training to single shoot when average height of tallest shoots was $38 \mathrm{~cm}$ (15.0 inches) produced 1-m (3.28-ft) tall nursery trees in 7.5 months, with training restricted to the last 2.5 months. Taller plants [1.17 $\mathrm{m}(3.84 \mathrm{ft})]$ and some lateral shoots growing above 1 $\mathrm{m}$ were produced following another 0.5 month of growth. Five training months were needed to produce 1.43$m$ (4.69-ft) trees if training was initiated when main shoots were only $16 \mathrm{~cm}$ (6.3 inches). Initiating training at the beginning of the growing season did not produce significantly taller trees. U ntrained plants only reached a height of $69 \mathrm{~cm}(27.2$ inches) at the end of the test period. eak apical dominance of the olive (Olea europaea) allows lateral buds to develop at the shoot base. Basal lateral shoots then become strong sinks for assimilates and grow rapidly, eventually becoming thicker and taller than theshootsfrom which they originated. $\mathrm{N}$ ursery olive trees develop as bushes, unless these basal lateral shoots are removed (Caballero and del Río, 1997).

This natural growth pattern is a serious constraint for nurseries pro-

D pto. Olivicultura y Arboricultura Frutal, CIFA Alameda del O bispo (J unta de Andalucía), A partado 3092, 14080 Córdoba, Spain.

To I gnacio L orite, for his assistance in propagating and training plants. The cost of publishing this paper was defrayed in part by the payment of page charges. U nder postal regulations, this paper therefore must be hereby marked advertisement solely to indicate this fact. 
ducing 1-m (3.28-ft) tall single-shoot trees with no lateral shoots below that height. A tall, single-shoot nursery tree is preferred to a shorter one because it has a good root system and needs less training to establish its canopy at 90 to $100 \mathrm{~cm}$ (35.4 to 39.4 inches) above soil level (C aballero and del Río, 1997; García-O rtiz et al., 1997; Sibbett and O sgood, 1994). Training this tree in theorchard consistsof letting itscanopy grow unrestricted for 3 to 4 years, then confirming the main scaffold branches and removing those falling to ground from either the trunk or the main branches. Some shoot thinning also may be needed inside the canopy at that time and for some more years. In this way the tree is trained to support heavy crops and to be suitable for mechanical harvest by a trunk shaker. This limited training during the first few years in the orchard resultsin rapid growth and early production, at lower pruning costs than when planting shorter nursery trees (G arcía-O rtiz et al., 1997).

A recent paper reviewed factors affecting the rooting of olive softwood cuttingsunder mist ( $C$ aballero and del Río, 1997). H owever, less attention has been paid to determine how to grow rooted cuttings in the nursery (Preziosi and Tini, 1990; T attini et al., 1990a, 1990b). So, most olive nurseries plant those rooted cuttings in plastic bags of $\approx 3 \mathrm{~L}(0.79$ gal) capacity filled with silty-sand soils, complemented with soil and/ or foliar fertilizers. In this way a single-shoot tree, 60 to $80 \mathrm{~cm}$ (23.6 to 31.5 inches) tall is produced in 1 year (Fontanazza, 1984; Preziosi and Tini, 1990; Sutter, 1994). For taller trees a second growing season isneeded (Preziosi and Tini, 1990; Sibbett and O sgood, 1994). Thetraining procedure for these plants usually consists of eliminating all but one of the shoots that grow from the rooted cutting. At all times, lateral shoots are removed from this single-shoot tree, except those developing at its upper one third (Caballero and del Río, 1997). H owever, no experimental data are available about when to initiate training.

O ur objective was to determine the height of main shoot at which to initiate the training of potted plants in the nursery, so that a saleable, tall olive nursery tree could be obtained in a single growing season without excessive pruning costs.

Hortlechnology • July-September 1999 9(3)

\section{Materials and methods}

'Picual' olive was used for the experiment because it is the most important cultivar in Spain, where it is grown on $\approx 650,000$ ha ( 1.6 million acres). I t is also among the most used in some of the countries where olivegrowing acreage has increased in recent years. It is easy-to-root, productive, has good fruit size and oil yield, and is easy-to-harvest ( Barranco and Rallo, 1984; del Río et al., 1986; $N$ ahlawi et al., 1975). 'Picual' softwood cuttings $14 \mathrm{~cm}$ (5.5 inches) tall were rooted under mist and potted into $9 \times 11-\mathrm{cm}(3.5 \times 4.3$-inch $)$ peat pots containing a $1: 1(\mathrm{v} / \mathrm{v})$ mixture of alkaline peatmoss (Floragard $\mathrm{GmbH}$, D-26135 O Idenburg, Germany) and silty sand. Those rooted cuttings then grew in the same greenhouse for $\approx 10$ $d$, until at least one lateral shoot per plant had grown 2 to $3 \mathrm{~cm}$ (1 inch) (C aballero and del Río, 1997).

After this hardening period those rooted cuttings were planted into 3-L plastic bags of black polyethylenefilled with the medium described aboveand grown in a greenhouse from $\mathrm{N}$ ovember 1996 until the beginning of $M$ arch 1997, when they were transferred to a lathhouse to continue growing until July of that year. To simulate spring growing conditions, the greenhouse was provided with a 14-h photoperiod by means of high pressure halogen lamps of $2000 \mathrm{mmol} \cdot \mathrm{m}^{-2} \cdot \mathrm{s}^{-1}(1000 \mathrm{w})$, whose height above the plants was changed with timeso that upper leaves would receive light intensity of 400 to $500 \mathrm{mmol} \cdot \mathrm{m}^{-2} \cdot \mathrm{s}^{-1}$. A temperature range of 14 to $28 \cong \mathrm{C}$ ( 57 to $82^{\circ} \mathrm{F}$ ) was used in the same greenhouse. In the lathhouse temperature ranged from 15 to $18{ }^{\circ} \mathrm{C}\left(59\right.$ to $\left.64^{\circ} \mathrm{F}\right)$ to 25 to $28 \stackrel{\circ}{\circ} \mathrm{C}$ ( 77 to $82^{\circ} \mathrm{F}$ ) from $M$ arch through $M$ ay, and to 28 to $32{ }^{\circ} \mathrm{C}\left(82\right.$ to $90{ }^{\circ} \mathrm{F}$ ) during June and July. Thus, plantswere grown for 8 months under conditions similar to those occurring during thenormal local growing season of $M$ arch through $O$ ctober. O nce a week each plant was irrigated with $400 \mathrm{~mL}(13.5 \mathrm{fl} \mathrm{oz})$ of water. Every 2 weeks a commercial fertilizer, $\mathrm{H}$ akaphos 15N-11P-15K (BASF E spañola SA, Barcelona, Spain), and Fe as Fe-EDDHA (Esantrene
H P, M assó SA, E-08029 Barcelona, Spain), were added to the water, at rates of $1 \mathrm{~g}^{\cdot \mathrm{L}^{-1}}(0.13 \mathrm{oz} / \mathrm{gal})$ and 0.94 $\mathrm{mg} \cdot \mathrm{L}^{-1}\left(1.25 \times 10^{-4} \mathrm{oz} / \mathrm{gal}\right)$, respectively.

The experiment was designed as a randomized block with four training treatments, replicated 18 times. O ne rooted cutting was used per replicate and treatment. T raining plantsto single shoot by eliminating all but the main shoot was initiated at four different dates (treatments): $0,3,5$, and 8 months after the initiation of the experimental growing season. This last treatment (8 months) was the control which wasleft unpruned until the conclusion of the experiment.

$\mathrm{H}$ eight of selected shoot, and number, length and dry mass of lateral shoots removed were recorded when treatments were initiated. Following treatment initiation, training was the same for all treatments: the selected shoot was kept bare by removing all growing lateral shoots every $15 \mathrm{~d}$, until the selected shoot reached $1 \mathrm{~m}$ (3.28 ft). Each shoot was kept vertical by staking. Shoot height was recorded every month. Average pruning time was recorded for each treatment every time training was performed. L aterals

Fig. 1. Influence of training initiation date (after $0,3,5$, and 8 months of growth) on height of olive nursery trees. Within each date different letters indicate significant differences ( $P=0.05$ ) among treatments according to T ukey's test $(2.54 \mathrm{~cm}=1.0$ inch).

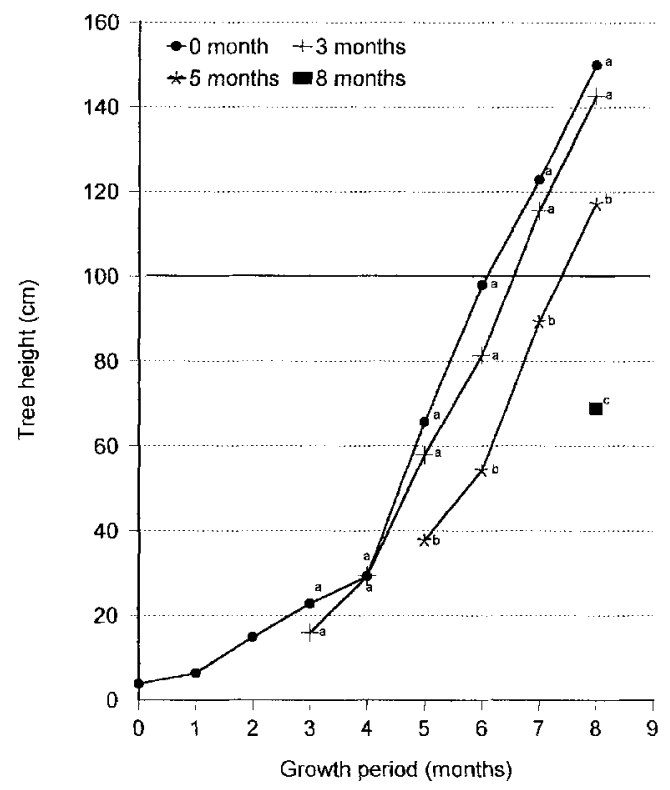


T able 1. N umber, length and dry mass of lateral shoots of nursery olive trees at the time of initiation training to single shoot $(25.4 \mathrm{~mm}=1.0 \mathrm{inch} ; 28.35 \mathrm{~g}=$ $1.0 \mathrm{oz}$ ).

\begin{tabular}{lccc}
\hline $\begin{array}{l}\text { Training } \\
\text { date }^{\mathrm{y}}\end{array}$ & \multicolumn{3}{c}{ Lateral shoots $^{\mathbf{2}}$} \\
\cline { 2 - 4 } & N umber & Length $\mathbf{( c m )}$ & Dry mass (g) \\
\hline 0 & $4.0 \mathrm{a}^{\mathrm{x}}$ & $2.9 \mathrm{c}$ & $0.4 \mathrm{~d}$ \\
3 & $5.8 \mathrm{a}$ & $5.6 \mathrm{C}$ & $2.3 \mathrm{C}$ \\
5 & $4.7 \mathrm{a}$ & $26.8 \mathrm{~b}$ & $7.2 \mathrm{~b}$ \\
8 & $4.2 \mathrm{a}$ & $46.0 \mathrm{a}$ & $21.7 \mathrm{a}$ \\
\hline
\end{tabular}

ZM ean of 18 plants.

yM onths since beginning of test period.

${ }^{x}$ Within each column different letters indicate significant differences $(P=0.05)$ among treatments, according to Tukey's test.

developing above $1 \mathrm{~m}$ on the selected shoot were allowed to grow.

Shoot diameter at $25 \mathrm{~cm}(9.8$ inches) height was measured in every plant at theend of the experiment. D ry massdistribution wasthen determined by separately drying roots and shoots of each plant during $48 \mathrm{~h}$ in a forced-

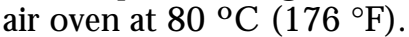

\section{Results and discussion}

U Itimate height of olive nursery trees was affected by the date of training initiation (Fig. 1). In the 8-month growing period used, trees did not differ significantly in final height if the elimination of all but the main shoot was done at the beginning of growing season or following 3 months of growth, when average height of these tallest shootswas $4 \mathrm{~cm}$ (1.6 inch) or 16 $\mathrm{cm}$ (6.3 inches), respectively. If training was initiated following 5 months of growth, when main shoots were 38 $\mathrm{cm}$ (15.0 inches) tall, final plant height wassignificantly shorter. T rained plants attained the desired $1 \mathrm{~m}$ height following either $6,6.5$, or 7.5 months of growth, and needed $6,3.5$, or 2.5 months of training, respectively. L ateral shoots had developed above $1 \mathrm{~m}$ in all trained trees. U ntrained trees grew as bushes consisting of several

shoots, the tallest reaching only $69 \mathrm{~cm}$ (27.2 inches) at the end of the test.

Length and dry mass of eliminated lateral shoots increased as the date of initiating training was delayed (Table 1). On the other hand, by test period end, dry mass accumulation in the selected shoot decreased with that delay; and root dry mass was larger for unpruned trees than for those whose training initiation date was after 3 and 5 months of growth, while those trained since beginning of growing season occupied an intermediate position (T able 2). These results confirm that all growing shoots act as metabolic sinks for available assimilates and show that pruned treeshave a total and shoot dry mass larger than unpruned ones. M oreover, trained trees did not differ significantly in root dry massand shoot diameter (Table 2). Therefore, to advance training initiation date would not diminish quality of resulting nursery tree.

Average number of eliminated shoots per plant was similar for all training initiation dates(Table 1 ). This result explains that the first training operation always took 5 min per plant; thelength of theeliminated shoots did not affect pruning time. $U$ ntil trees reached $1 \mathrm{~m}$ high, 3 more min per
Table 2. Shoot diameter and dry mass distribution of nursery olive trees following 8 months of growth $(25.4 \mathrm{~mm}=1.0 \mathrm{inch} ; 28.35 \mathrm{~g}=1.0 \mathrm{oz}$ ).

\begin{tabular}{lccc}
\hline Training & & \multicolumn{2}{c}{ Dry mass $\mathbf{( g )}$} \\
\cline { 3 - 4 } date $^{\mathbf{y}}$ & Shoot diam $(\mathbf{m m})^{\mathbf{x}}$ & Shoot & R oots \\
\hline 0 & $5.4 \mathrm{a}^{\mathrm{w}}$ & $33.6 \mathrm{a}$ & $4.3 \mathrm{ab}$ \\
3 & $4.6 \mathrm{a}$ & $25.5 \mathrm{~b}$ & $3.5 \mathrm{~b}$ \\
5 & $4.5 \mathrm{a}$ & $18.3 \mathrm{bc}$ & $3.4 \mathrm{~b}$ \\
8 & $4.3 \mathrm{a}$ & $9.7 \mathrm{C}$ & $7.5 \mathrm{a}$
\end{tabular}

זM ean of 9 plants.

yM onths since beginning of test period.

xM ean of 18 plants.

wWithin each column different letters indicate significant differences $(P=0.05)$ among treatments, according to Tukey's test. plant were used every $15 \mathrm{~d}$ to eliminate new laterals. So, total training required 41,26 , and 20 min per plant for the 0 , 3 , and 5 month training treatments, respectively. Thus, delaying the initiation of training resulted in savings in training time and, therefore, in plant production cost.

T aking into account the recorded growth and the training times used, the best date to initiate training of nursery olive trees is when the average height of the tallest shoots is $38 \mathrm{~cm}$ (15.0 inches), following $\approx 5$ months of growth. This practice produced $1-\mathrm{m}$ tall trees in just 7.5 months, with training restricted to the last 2.5 months. This height is considered the minimum for planting an olive tree, mainly because it avoids most training in the orchard (Caballero and del Río, 1997; G arcía-O rtiz et al., 1997). Additional height [up to $1.17 \mathrm{~m}(3.84 \mathrm{ft})$ ] was attained by letting plants grow in the nursery for another 0.5 month. This also allowed for lateral branching above $1 \mathrm{~m}$, thus constituting even better quality treesasthefuturemain scaffold branches are already growing when the tree is planted.

If plant growth is anticipated to be reduced due to a shorter growing season, the time required to produce 1 - $m$ tall plantscan be reduced 1 month by initiating training when their main shoots are $16 \mathrm{~cm}$ ( 6.3 inches) height, following $\approx 3$ months of unrestricted growth. To initiate training at the beginning of the growing season does not provide any significant advantage in tree height, but increases production costs because of the need to remove lateral shoots during 3 more months.

This work shows that training initiation date is a key factor in producing nurseryolivetreesin anormal 8-month growing season. The possibility of attaining good, marketable tree size by midfall, following one growing season, is very convenient for most olive nurseries, which root softwood cuttings during the previousfall and early winter.

\section{Literature cited}

Barranco, D. and L. Rallo. 1984. Las variedadesde olivo cultivadasen A ndalucía. M inisterio de Agricultura, Pesca y Alimentación-J untadeAndalucía, M adrid, Spain.

Caballero, J.M. and C. del Río. 1997.

Hortlechnology • July-September 1999 9(3) 
M étodosdemultiplicación, p. 89-113. In: D. Barranco, R. Fernández-Escobar, and L. Rallo (eds.). EI Cultivo del Olivo. 2nd ed. M undi-Prensa and J unta deA ndalucía, $M$ adrid, Spain.

del Río, C., L. Rallo, and J.M. Caballero. 1991. E ffects of carbohydrate content on the seasonal rooting of reproductive and vegetative cuttings of olive. J. H ort. Sci. 66:301-309.

García-O rtiz, A., A. Fernández, M . Pastor, and J. H umanes. 1997. Poda, p. 307-343. In: D. Barranco, R. Fernández-E scobar, and L. Rallo (eds.). El Cultivo del Olivo. 2nd ed. Mundi-Prensa and Junta de Andalucía, M adrid, Spain.
Fontanazza, G. 1984. Allevamento e potatura dell'olivo. U niversaleE dagricole, Bologna, I taly. p. 62.

N ahlawi, N ., L. Rallo, J.M . Caballero, and J. Eguren. 1975. A ptitud al enraizamiento del olivo por estaquillado herbáceo bajo nebulización. An. INIA/ Ser. Prod. Veg. 5:167-182.

Preziosi, P. and M. T ini. 1990. Determination of optimum pot size for nursery production of olive trees. Acta Hort. 286:81-84.

Sibbet, G.S. and J. O sgood. 1994. Site selection and preparation, treespacing and design, planting, and initial training, $p$. 31-37. In: L. Ferguson, G.S. Sibett, and
G.C. Martin (eds.). Olive production manual. Univ. Calif. Div. Agr. Natural Resources Publ. 3353.

Sutter, E.G. 1994. Olive cultivars and propagation, p. 23-29. In: L. Ferguson, G.S. Sibett, and G.C. M artin (eds.). O live production manual. U niv. Calif. Div. Agr. $\mathrm{N}$ atural Resources Publ. 3353.

Tattini, M ., P. Bertoni, M .L . T raversi, and P. N appi. 1990a. Waste materials as potting media in olive pot production. Acta H ort. 286:121-124.

Tattini, M ., A. Chiarini, R. T afani, and M. Castagneto. 1990b. Effect of humic acids on growth and nitrogen uptake of container-grown olive (Olea europaea L. 'M aurino'). Acta H ort. 286:125-128. 